DOI: $10.14451 / 2.153 .15$

\title{
ПРОБЛЕМЫ И ПЕРСПЕКТИВЫ ВЗАИМОДЕЙСТВИЯ ИНСТИТУТОВ ГРАЖДАНСКОГО ОБЩЕСТВА С ОРГАНАМИ ИСПОЛНИТЕЛЬНОЙ ВЛАСТИ
}

\author{
(c) 2021 Казанкова Татьяна Николаевна \\ кандидат педагогических наук \\ Самарский государственный экономический университет, Россия, Самара
}

(c) 2021 Подгорнова Людмила Александровна

инспектор отдела по вопросам миграции

В статье раскрываются проблемы, которые проявляются у собственника жилого помещения, в процессе доказывания вины управляющей компании в неисполнении договора между ними. Рассмотрена группа ошибок в данной области. Проведен анализ законодательной базы обеспечения права по договорным обязательствам в рамках жилищного права. Выявлены пробелы в законодательстве РФ в данной области, а также сформированы дальнейшие направления устранения выявленных пробелов.

Ключевые слова: договор, ответственность, протокол, Гражданский кодекс Российской Федерации, Федеральный закон.

В современных условиях все острее стоит вопрос осуществления управления многоквартирным домом. Особенно данная тенденция касается осуществления предпринимательской деятельности в России. Соответственно, актуальным является вопрос рассмотрения проблем в процессе доказывания вины управляющей компании ввиду неисполнения договорных отношений.

Стоит обратить внимание на тот факт, что статья 192 Жилищного кодекса РФ, гласит о том, что осуществление данного вида деятельности, может быть доступно только при наличии лицензии, которая выдается лицензионной комиссией государственного жилищного надзора РФ.

Это обстоятельство справедливо определяет необходимость более детального изучения деятельности руководителей компании с целью обеспечения ее оптимального функционирования, так как особенно влияет на качество жизни населения [1].

Чтобы понимать предмет описания необходимо уточнить, что частное значение в деятельности имеет правовое регулирование отношений собственников и компании, осуществляющей надзор за его общим состоянием. Из этого следует, что связь между собственником и руководящей собственностью компанией, которая выполняет этот вид деятельности, регулируются такими актами: Гражданский кодекс, Гражданский процессуальный кодекс Российской Федерации, жилищное право Российской
Федерации, «Правила совместного управления имуществом». Постановление Правительства РФ, Федеральный закон «О защите прав потребителей».

В свою очередь, договорный тип правоотношений, так или иначе, подразумевает несколько важных нюансов, в ходе которых рассматриваются обоюдные права и обязанности, а также вопросы ответственности за неисполнение договорных отношений. Сопряжение проблемных факторов исполнения контрагентами договорных отношений при возможном наступлении ответственности, способны сформировать негативное отношение населения к данному сегменту предпринимательской деятельности в целом. А также чувству незащищённости населения от посягательств на их гражданские и имущественные права в случае действий, либо бездействий сотрудников управляющих компаний, осуществляющих свою деятельность на основании заключаемых с ними договоров, которые влекут за собой порчу, разрушение имущества лица, в ряде случаев повлекшее за собой ухудшение здоровья.

Следствием причинения вреда, является деликт, то есть правонарушение, которое способно причинить вред личности или имуществу определенного лица. Наступлением ответственности вследствии причинения вреда является система юридических фактов, которые формируют состав деликатного обязательства, куда принято относить: наличие вреда, противоречивое по- 
ведение примирителя вреда, вина примирителя вреда. В случаи неисполнения договорных обязательств, принятых на себя компанией, осуществляющей управление при заключении договора на управление общедомовым имуществом получая за это оплату также является правонарушителем прописанных в Гражданскопроцессуальном кодексе Российской Федерации.

Однако в случае возмещения убытков истец должен доказать законность правонарушения ответчиками, его последствия с точки зрения ущерба, причинную связь между ними, размер причиненного ущерба, а также отсутствие вины, вызванной ущербом, наличие исключительных обстоятельств ответственность за возникновение или приведение к наложению ограниченной ответственности.

При рассмотрении проблематики и для дальнейшего разрешения вопросов связанных с рассматриваемым вопросом следует выделить группу характерных ошибок.

Во-первых, как и в любом вопросе необходимо ознакомление с договором руководству многоквартирным домом, пока это необходимо акцентировать внимание на обязанностях управляющей организации, приложениях, а также необходимых реквизитах, для последующего их использования при составлении документации. Необходимо не просто составление первичного акта осмотра, но и использование права обращения в такие государственные органы, как орган местного самоуправления, Государственная жилищная инспекция, которые определяются как гаранты соблюдения нормативноправовых актов, за разъяснением своих прав, а также получения помощи в составлении претензии в управляющую компанию, составлении комиссионного акта осмотра повреждений и фиксации причинения вреда, дальнейшего составления искового заявления при невозможности урегулирования конфликта в досудебный период.

Следует отметить, что потребитель имеет право предоставлять услугу в нормальных условиях использования в соответствии с требованиями безопасности и уровня жизни. потребителю, окружающей среде и не причиняет материального ущерба, которые являются обязательными и предусмотрены законодательством [2].

Согласно статье 151 Жилищного кодекса, на первом месте перед руководством за состоянием дома стоит задача по обеспечению положи- тельных и защищенных состояний помещения. И содержит в себе описание обязательств, за надлежащее выполнение которых последует ответственность в рамках действующего законодательства [1].

Согласно статье 10 Постановления Правительства РФ необходимо осуществлять должное содержание общего имущества. Гарантировать непрерывную готовность технических средств и средств измерений, входящих в состав имущества, для оказания услуг, то есть коммунальных услуг, людям, проживающим в многоквартирном доме [3].

Ко второй группе ошибок, которые допускаются при решении возникающих вопросов, можно отнести содержание составляемых документов. При тщательном анализе судебной практики имеется возможность сделать вывод, что непризнание документальных свидетельств судами в качестве доказательства во многих случаях связанно именно с неправильным их оформлением, отсутствием необходимой и полной информации, не имением научной обоснованности, несоответствием требованиям закона, отсутствием вытекающих из изложенного выводов, строго оговоренных временных рамок для выполнения тех, или иных условий. Согласно закону «О защите прав потребителей» дефекты в работе должны быть устранены в соответствующий срок, который должен быть определен потребителем. [2].

Управляющая компания со своей стороны отвечает за все нарушения, которые связаны с уровнем качества предоставляемых услуг; вредом здоровью или жизни индивиду; убыткам, которые были причинены ввиду нарушение договорных отношений; ненадлежащем информировании о коммунальных услугах [3].

Также важно обратить внимание, что в соответствии с нормированием технической эксплуатации жилого дома, необходимо обеспечивать должны уровень влажности внутри дома, его теплозащиту, влагозащиту наружных стен. Данный контроль и осуществление должно происходить со стороны организации по обслуживанию данного жилищного фонда. В случае выпадения конденсата и образование плесени в жилом доме, нужно незамедлительно устранить источник увлажнения воздуха и реализовать качественный уровень проветривания подвала или иного технического оборудования в зависимости от строения [3]. 
Статья 154 Конституция Российской Федерации и законом о предоставлении коммунальных услуг, гласит о том, что для восстановления нарушенного права должны быть возмещены убытки или любые расходы, понесенные потребителем, права которого были прямо нарушены. Он также имеет право на компенсацию утраченного дохода, на который лицо имело право в обычных условиях гражданского оборота, но не получило его, поскольку в этой ситуации его право было нарушено [3].

Понятие поддержания собственности дома в том числе подразумевает его осмотры для выявления нарушений договора, законодательства Российской Федерации; текущий и капитальный ремонт, подготовку к различным погодным условиям и общего его содержание [3].

Инспекция мест общего пользования оформляются документами, которые является причиной принятия собственниками либо лицами, ответственными за принятие решения о соответствии или несоответствии контролируемого совместного имущества или элементов общего имущества, а также требованиям закона, обеспечивающим безопасность граждан, включая меры, касающиеся любых текущих мер, направленных на устранение и выявление недостатков.

Со стороны Пленума ВС РФ разъясняется, что суд в процессе защиты прав потребителей, которое добровольно не удовлетворено производителем, имеет возможность наложения штрафных санкций, даже если не было прошений суду [4].

Также согласно статье 68 ГК РФ возможно возмещение судебных расходов той стороне, в чью пользу было принято процессуальное решение [5].

К следующей и не менее важной группе ошибок следует отнести те, ошибки, которые непосредственно связаны с доказыванием наступления ответственности по договору, которые в большинстве своем носят процессуальный характер. Несоблюдение уведомительного порядка при составлении актов осмотра, дефектных актов, если мы говорим, о визуальном, а также инструментальном осмотре мест повреждения, который влечет за собой проблемы при доказывании в суде, либо иных инстанциях вины управляющей компании.
Итак, доказательство наличия убытков лишь одно из условий из множества возможных условий необходимых для возложения ответственности на управляющую компанию.

Из чего можно вынести положение о том, что обнаружение какого-либо дефекта конструкций дома еще не является свидетельством того, что в управлении домом есть нарушения законодательства и необходимо установить причину неправомерных действий данного управления, а также фактов повреждения имущества и причиненных убытков.

На практике, как правило, нетрудно доказать причинно-следственную связь, если в контракте четко прописаны условия и порядок осуществления управленческой деятельности. Если это условие будет четко объяснено, будет менее проблематично доказать вину контрагента, которая стала причиной его несоблюдения.

Таким образом, собственник должен соблюдать свою часть договора, включая оплату содержания, содержания, а также осуществления капитального ремонта имущества в жилом доме, добровольно выполняя свою часть договора [1].

В соответствии со статьей 29 Закона, потребитель имеет право потребовать, среди прочего, немедленного устранения нарушения в предоставленной услуге, а также запросить полную компенсацию убытков, которые были понесены в ходе реализации представленной услуги и ненадлежащего ее исполнения [2].

Как итог можно сделать вывод, что существует необходимость закрепления на законодательном уровне форм договоров на управление многоквартирным домом с обязательным описанием в нем персональной ответственности лиц, осуществляющих хозяйственная деятельность по управлению домом.

А также содержанием в договоре в обязательном порядке информации о порядке действий в случае нарушения договорных условий, а также утвердить формы актов, которые бы содержали всю необходимую информацию, чтобы нести в себе доказательную базу в случае обращения в суд.

Необходимо также в нормативно-правовые акты внести ответственность лицензиата, за деятельность тех, кому эти лицензии выдаются. 


\section{Библиографический список}

1. Жилищный Кодекс Российской Федерации. Параграф девять, десять: Федер. закон от 19 декабря 2002 г. № -Ф3: принят Гос. Думой 22 декабря 2004 г: База данных «Консультант Плюс». База данных «Консультант Плюс». Retrieved from: http://www.consultant.ru/document/cons_doc_LAW_51057/ / (дата обращения: 20.09.2020)/.

2. Закон Российской Федерации от 07.02.1992 г. № 2300-1 «О защите прав потребителей» (в ред. Федер. закона от 24.04.2020 г. № 144-Ф3) База данных «Консультант Плюс». Retrieved from: http://www.consultant.ru/ document/cons_doc_LAW_305/ / (дата обращения 24.09.2020)/.

3. Постановление Правительства Российской Федерации от 13.08.2006 № 491 «Об утверждении Правил содержания общего имущества в многоквартирном доме и правил изменения размеров платы за содержание жилого помещения в случае оказания услуг и выполнения работ по управлению, содержанию и ремонту общего имущества в многоквартирном доме ненадлежащего качества. База данных «Консультант Плюс». Retrieved from: http://www.consultant.ru/document/cons_doc_LAW_62293/ / (дата обращения 24.09.2020)/.

4. Постановление Пленума Верховного Суда Российской Федерации от 28.06.2012 «О рассмотре6нии судами гражданских дел по спорам о защите прав потребителей» База данных «Консультант Плюс». Retrieved from: http://www.consultant.ru/document/cons_doc_LAW_131885// (дата обращения 24.09.2020)/.

5. «Гражданский процессуальный кодекс Российской Федерации» Федер. закон от 14 ноября 2002 г. № $138-$ Ф3: принят Гос. Думой 23.11.2002 г: одобр. Советом Федерации 30.11.2002 г. // База данных «Консультант Плюс». Retrieved from: База данных «Консультант Плюс». Retrieved from: http:/www.consultant.ru/document/ cons_doc_LAW_395720// (дата обращения: 24.09.2020)/. 